\title{
Reflections On Crossing The Boundaries Between Public And Private Law In Implementing The "European Green Deal."
}

\author{
Tomasz Bojar-Fijałkowski \\ Kazimierz Wielki University in Bydgoszcz, Poland \\ tbojar@ukw.edu.pl
}

Submitted: Aug 3, 2021; Reviewed: Oct 11, 2021; Accepted: Oct 18, 2021

\section{Info Artikel}

Keywords: European Green Deal, European Union, circular economy, environmental law, public law, private law.

\section{DOI:}

https://doi.org/10.25041/aelr.v2i2.2397

\section{Abstract}

Climate change brings new challenges to the world. With its high environmental standards, the European Union is one of the most active players in global climate action. We are currently witnessing an extremely rapid process of transforming the political doctrine of the European Union into hard-law standards legal system. The so-called "European Green Deal" implements ideas of sustainable development in the area of, among others, energy, waste, but also transport, construction and electronic equipment sectors. One of the instruments for implementing the "European Green Deal" is the "Circular Economy", which, using European Union law, profoundly interferes with the economic freedoms of entrepreneurs but also consumers. Observing these activities can be interesting, especially when viewed from a certain distance and critical perspective.

This text is devoted to analysing selected regulations constituting the currently created "European Green Deal" and its agenda. It also aims to indicate regulations interference in the sphere of private law, which has not yet been so much the domain of environmental law. The author presents a hypothesis on a gradual transgression of the traditional boundary between public and private law or the blurring of that boundary in the case of recent environmental legislation of the European Union.

The dogmatic-legal analysis applied to the currently binding regulations for a fuller understanding also requires the application of the historical-legal method to earlier regulations. Their joint application makes it possible to indicate the direction of the new law dedicated to implementing the newest 
environmental-legal doctrine of the European Union. The layout of the study was subordinated to this aim, as well as its structure. The study is based on national and international literature on business law, environmental law and administrative law. Legal status up to date as of 31.07.2021.

\section{A. Introduction}

In 1983, the United Nations Commission on Environment and Development presented "Our Common Future." ${ }^{1}$ Which defined sustainable development for the first time. Since then, sustainable development has often been referred to in international law. ${ }^{2}$ Sustainable development, as a principle, has also been included in the Polish Constitution. ${ }^{3}$ Particularly in article 5, which states that "the Republic of Poland shall safeguard the independence and inviolability of its territory, ensure freedom and human and civil rights and the security of its citizens, protect the national heritage, and ensure environmental protection while following the principle of sustainable development". Through such a provision, sustainable development is a principle of environmental law and refers to economic development, security, and even preservation of independence. It is often described as a general constitutional rule or metaprinciple of law.

Despite numerous political declarations, global warming is not slowing down. The number of acts of international law and the development of international organisations is, in this respect, inversely proportional to the effects. One of the relatively positive players in this fight for the fate of future generations is the European Union $^{4}$ who is a leader in the implementation of environmental law for decades. ${ }^{5}$

The "European Green Deal" It is the name of a significant new development strategy and policy designed to bring an environmentally friendly transformation of the EU economy. The EU is to achieve ambitious targets for reducing emissions, developing innovative technologies and innovations while at the same time protecting the environment. The aim is for the EU to become a climate-neutral area by 2050. To do this, specific legal acts have already been adopted, such as the "European Climate Law"7, which is binding on all 27 EU member states. EGD will thus transform political commitments into legal commitments. There is, therefore, a rare opportunity in the history of environmental law to equip the idea of sustainable development with hard-law instruments. Achieving this will require deep intervention in at least several sectors of the economy through:

\footnotetext{
${ }^{1}$ Hans Christian Bugge and Christina Voigt, Sustainable Development in International and National Law: What Did the Brundtland Report Do to Legal Thinking and Legal Development, and Where Can We Go from Here? (Portland: Avosetta, 2008).

2 These include the 1972 Stockholm Conference "Only One Earth" and the 1992 United Nations Conference in Rio de Janeiro "Environment and Development" and subsequent editions.

3 “Constitution of the Republic of Poland," Pub. L. No. 483 of 2 April 1997, 2413 (1997).

4 The European Commission, “EU', a Political and Legal Community of 27 European States," European

Union, 2021, https://doi.org/10.2775/5377.

${ }^{5}$ Bojar-Fijałkowski T, “On the Ideas Shaping European Union Environmental Law. Part I: From Sustainable Development," Problemi Mižnarodnih Vidnosin 13 (2018): 148-66, https://repozytorium.bg.ug.edu.pl/info/article/UOG797cd3383d334e2e9cf1df193f729022/?ps=20\&lang=en\&p $\mathrm{n}=1 \& \mathrm{cid}=201 \#$. YYCw3J5BzIU.

6 The European Commission, "European Green Deal” (2019), https://www.unido.org/sites/default/files/files/2020-11/EU_Green_Deal_2020.pdf.

${ }^{7}$ Council of the European Union, "Regulation (EU) 2021/1119 Establishing the Framework for Achieving Climate Neutrality ('European Climate Law'),” Pub. L. No. 2021/1119, 1 (2021).
} 
- Investment in environmentally friendly technologies;

- Promotion of eco-innovation in the industry;

- Introducing cleaner, cheaper and healthier modes of transport;

- Decarbonising the energy sector;

- Making buildings more energy efficient;

- Working with international partners to improve global environmental standards.

The EGD needs to be equipped with standards like any political idea, as the law is fundamental for implementing environmental policy. ${ }^{8}$ All the more so as interference in the above business activities may infringe economic freedom, which is often the subject of public law.

We can also observe the same environmental approach during the ongoing post-Brexit negotiations between the EU and the United Kingdom. The EU announced that only if its former member maintains the same high social and environmental standards will the UK access the EU's open market of goods and services. ${ }^{9}$ The EU will regard the setting of other, lower standards as an act of unfair competition. We can assume that it is only a matter of time before the EU declares unfair imports from other countries and regions that do not meet similar and high standards, especially environmental standards. ${ }^{10}$ This could result in valid tariffs on goods produced by producers with less environmental commitment and offer on the market competitive to EU goods. In such a case, environmental objectives will be pursued in parallel to economic objectives.

In the face of the SARS-Cov-2 pandemic, the doctrine of the EGD takes on added significance. In addition to ecological goals, there is an incredibly motivating economic goal of rebuilding the economy after the pandemic. New technologies, green investments, and renewable energy are the flywheel of economic development to improve the quality of life of current and future generations. ${ }^{11}$ At the same time, this economy must be modern, resourceefficient, and competitive and zero-emission. The aim is also to protect the health and wellbeing of citizens against the risks and adverse effects of climate change. ${ }^{12}$

\section{B. Discussion}

\section{Circular economy as part of "European Green Deal."}

"European Climate Law" has indicated that greenhouse gas emissions must be reduced and removals increased so that net greenhouse gas emissions, i.e. emissions minus removals, are reduced across the member states economy and at the EU level by at least $55 \%$ by 2030 compared to 1990 levels. This is already included in hard law as a limit to be achieved, and EU member states will be held accountable for meeting this target. There are heavy financial penalties for non-compliance with EU law.

Another element of the implementation of the EGD is the "Circular economy." ${ }^{13}$ which appeared for the first time in the waste management strategy with the title "Towards a circular

\footnotetext{
${ }^{8}$ Ciechanowicz-McLean J, Prawo i Polityka Ochrony Środowiska, ed. Anna Hara (Warszawa: Wolters Kluwer, 2009).

${ }^{9}$ Stuart Evans et al., "Border Carbon Adjustments and Industrial Competitiveness in a European Green Deal," Climate Policy 21, no. 3 (2021): 307-17, https://doi.org/10.1080/14693062.2020.1856637.

${ }^{10}$ Kersty Hobson, "The Limits of the Loops: Critical Environmental Politics and the Circular Economy," Environmental Politics 30, no. 1-2 (2021): 161-79, https://doi.org/10.1080/09644016.2020.1816052.

${ }^{11}$ Sebastian Oberthür and Claire Dupont, "The European Union's International Climate Leadership: Towards a Grand Climate Strategy?," Journal of European Public Policy 28, no. 7 (2021): 1095-1114, https://doi.org/10.1080/13501763.2021.1918218.

12 Nicolas De Sadeleer, "EU Environmental Law and the Internal Market," Review of European, Comparative \& International Environmental Law 26 (2014): 101-2, https://doi.org/10.1111/reel.12191.

13 Sadeleer.
} 
economy: a zero waste programme for Europe." ${ }^{14} \mathrm{CE}$ is a development strategy that assumes economic growth without increasing resource consumption, a profound transformation of production chains and consumption habits and a transformation of industrial systems at a systemic level. ${ }^{15}$ It is based on technological, social and organisational innovation. It requires a new range of skills and knowledge, new financial instruments, and the involvement of multiple stakeholders. It can be supported by market uptake of innovation and awarenessraising, dissemination, and internationalisation activities. ${ }^{16}$

Among the objectives of $\mathrm{CE}$, reducing the number of materials required to provide specific service and extending the life of products, i.e. their durability, play an essential role. Reducing energy and material consumption in the production and use phases, i.e. improving efficiency and reducing the use of hazardous or difficult to recycle materials, is called for. The creation of markets for secondary raw materials based on specific standards and new public procurement regulations are also mentioned as methods to reach the CE objectives. COM/2014/0398 also points to the need to design products that are easier to maintain, repair, upgrade, rework or recycle, referred to as "eco-design", and the need to maintain and repair products rather than dispose of them and replace them with new ones. It is also about stimulating conditions for more and better consumer choices through renting or sharing services as an alternative to ownership of products while safeguarding consumer interests in terms of costs, information, contractual conditions and insurance aspects. This implementation of actions is seen based on private law.

Regulations aimed at conscious, sustainable consumption and better products are not new to EU legislation. The 2005 Ecodesign Directive ${ }^{17}$ Established ecodesign requirements for energy-using products. However, it did not introduce directly binding requirements for individual products. Still, it only emphasised ensuring the free movement of these products on the internal market, taking into account their life cycle. Similarly, in the European Commission's view, incentives for green public procurement have been insufficient. While it was previously stressed that voluntary measures would strengthen green public procurement, today, ius cogens standards are already being called for in this respect. ${ }^{18}$ Currently, there are laws in progress implementing the $\mathrm{CE}$ assumptions in the following areas: waste management; packaging and packaging waste; waste storage; end-of-life vehicles, batteries and accumulators, and waste electrical and electronic equipment. ${ }^{19}$

Against this legislative backdrop, Commission Regulation (EU) 2019/2019 of 1 October 2019 is a landmark. ${ }^{20}$. It establishes ecodesign requirements for the placing on the market or putting into service of mains-operated refrigerating appliances with a total volume more

\footnotetext{
${ }^{14}$ The European Commission, "Communication From The Commission To The European Parliament, The Council, The European Economic And Social Committee And The Committee Of The Regions Towards a Circular Economy: A Zero Waste Programme for Europe" (2014).

15 Zbigniew Bukowski, Gospodarka o Obiegu Zamkniętym a Prawo Ochrony Środowiska, ed. BojarFijałkowski T (Gdansk, 2016).

${ }^{16}$ Nicky Gregson et al., "Interrogating the Circular Economy: The Moral Economy of Resource Recovery in the EU," Economy and Society 44, no. 2 (2015): 218-43, https://doi.org/10.1080/03085147.2015.1013353.

${ }^{17}$ European Parliament and Council, "Directive 2005/32/EC of the European Parliament and of the Council of 6 July 2005 Establishing a Framework for the Setting of Ecodesign Requirements for Energy-Using Products and Amending Council Directive 92/42/EEC and Directives 96/57/EC and 2000/55/EC ," Pub. L. No. 191, 22.7.2005, 29 (2005).

${ }^{18}$ The European Commission, "EU Green Public Procurement Criteria for Road Lighting and Traffic Signals" (2018).

${ }^{19}$ Bojar-Fijałkowski T, Gospodarka o Obiegu Zamkniętym Jako Model Rozwoju Unii Europejskiej - Wyzwania Dla Wybranych Sektorów, ed. M. Królikowska-Olczak and C.H. Beck (Warszawa: problematyka prawna, 2018).

${ }^{20}$ The European Commission, "Laying down Ecodesign Requirements for Refrigerating Appliances Pursuant to Directive 2009/125/EC of the European Parliament and of the Council and Repealing Commission Regulation (EC) No 643/2009,” Pub. L. No. (EU)2019/2019, 2019187 (2019).
} 
significant than 10 litres but less than or equal to 1,500 litres, in practice refrigerators. According to the wording of Annex II of Regulation 2019/2019, the manufacturer or importer may not offer and market equipment that does not meet the requirements of energy efficiency, functionality, resource efficiency, availability of spare parts. ${ }^{21}$, maximum delivery time ${ }^{22}$ The regulation also provides for a verification procedure for market surveillance purposes. Analogous rules are foreseen for dishwashers, washing machines and dryers.

\section{Modern EU environmental regulations between public and private law}

Dividing law according to the criterion of the method of regulation, private law is a set of norms shaping the relations between legal entities, taking into account the principle of equality, autonomy and freedom in shaping legal relations. A feature of private law understood in this way is the lack of possibility for one party to a legal relationship to exercise sovereign influence over the other party regarding its rights and obligations. ${ }^{23}$ Adopting the same criteria, public law should be regarded as a set of norms regulating the organisation and behaviour of public administration bodies. Public law subjects not subordinated to it, with the use of state authority, thanks to which these bodies may, and often have the task to, interfere in the sphere of rights and obligations of such subjects and shape them unilaterally.

Theoretically clear boundaries of public and private law in practice are increasingly blurred, intertwined, mixed, and hybrid entities are created. As argued by E. T. Szuber-Bednarz and R. Paczuski argue that the process of replacing the traditional forms of action of public administration with private law forms results from the general socio-economic model. Thus, in practice, we often observe contracts concluded as a result of administrative proceedings ${ }^{24}$, the growing role of mediation in public law proceedings ${ }^{25}$, commercial law companies carrying out activities highly restricted under their ownership composition ${ }^{26}$ And entities with limited freedom of contract. ${ }^{27}$

The interpenetration of public law norms with private law norms is evident in the area of real estate management law and environmental law. Examples in environmental law are civil liability, the economic activity of the state and local self-government, public management, which introduces instruments created and developed by private administration into public

21 The regulation states that manufacturers, importers of refrigeration appliances or their authorised representatives shall keep at the disposal of professional repairers for at least seven years after the last unit of the model concerned has been placed on the market the following spare parts: thermostats, temperature sensors, printed circuit boards handles, door hinges, trays and baskets for a period of at least seven years and door seals for a period of at least 10 years after the last model has been placed on the market; manufacturers shall ensure that those spare parts can be replaced with commonly available tools without permanent damage to the appliance; a list of spare parts and the procedure for ordering them shall be made publicly available on the manufacturer's, importer's or authorised representative's website accessible to the public at the latest two years after the first unit of a given model has been placed on the market and until the end of the availability period of those spare parts.

${ }^{22}$ Maximum delivery time for spare parts: the manufacturer, importer or authorised representative shall ensure the delivery of spare parts for refrigeration appliances within 15 working days of receipt of the order. For spare parts available only to professional repairers, this availability may be restricted to professional repairers.

${ }^{23}$ Safjan M, Pojęcie i Systematyka Prawa Prywatnego, ed. M. Safjan (Warszawa: Wolters Kluwer, 2007).

${ }^{24}$ Concluded as a result of public procurement procedures.

25 The Republic of Poland, "Polish Code of Administrative Procedure" (1960),

http://www.parliament.am/library/varchakaniravaxaxtum19/lehastan.pdf.

26 Andrzej Powałowski, "Skarb Państwa a Działalność Gospodarcza [State Treasury and Economic Activity]," Gdańskie Studia Prawnicze, 2017, 527-38, https://prawo.ug.edu.pl/sites/default/files/_nodes/stronapia/33461/files/38powalowski.pdf.

${ }^{27}$ Bojar-Fijalkowski T and Cern G, Ograniczenia Działalności Gospodarczej Spótki Komunalnej - Uwagi

Krytyczne [Restrictions on the Economic Activities of a Municipal Company - Critical Remarks, ed. A.

Pławska M. Geryk (Gdansk: WSZ, 2016). 
administration. ${ }^{28}$. The visible interpenetration of private and public law does not necessarily mean that public law is being superseded. ${ }^{29}$. Following J.S. Langrod, it can be assessed that public law extracts from older and more developed private law legal constructs that are helpful in public administration activity. ${ }^{30}$

It is worth stressing that parallel to supplanting or replacing public law with private law, a reverse process may also be observed. M. Safjan calls it the publication of civil law, which is to involve a departure from the assumptions of classical civil law, and increasingly substantial interference of the public factor in the sphere of autonomy of individual behaviour, including limiting the field of application of the private-law method in favour of public-law regulations ${ }^{31}$ Hence, at the same time, as civil law increases in the activity of public administration, we can also observe the influence of public administration on the shaping, undertaking and performance of private-law contracts. This happens especially in the sphere of public business law, where the norms of administrative law shape the legal relationship to an increasing extent, limiting the principle of freedom of contract and freedom of entrepreneurship.

The contemporary EU legislator also does this, often limiting the freedom of contract, freedom of entrepreneurship, values crucial for civil law, including commercial law, through numerous conditions, standards, procedures and limitations. In pursuing the objectives of the $\mathrm{CE}$, it does so by interfering very clearly in the design of goods, their supply chain, durability, repairs, delivery times for spare parts. Traditionally, all this was left to the entrepreneur's freedom. The only person who controlled the quality, apart from his products' safety, materials, and durability, was the market and his contractors. Today, EU law interferes in this by, among other things, implementing the EGD and banning specific energy solutions or burdening them with such hefty fees and taxes that they become uncompetitive and lose customers.

A problem in the field of theory of law is assessing the changes currently taking place. On the one hand, crossing the boundaries between the sphere of the individual and the sphere of the dominion of state authority raises concerns and doubts. The discussion about the competencies of the common authorities of the EU over the member states continues. The issue of expanding the areas of common EU regulations may also be an element of this discussion. Member states are beginning to question such measures, although this does not yet directly concern climate action. Doubts should also be raised as to the stability and homogeneity of the legal system as we know it. The measures described in the text certainly disrupt this homogeneity.

On the other hand, crossing the boundaries between public and private law is not a new invention. It has happened before, and the area of climate change is undoubtedly one that justifies taking non-standard, atypical, but effective action. Traditional divisions do not necessarily correspond to the challenges of today's dynamic society and economy. Hybrids can function equally well in technology, economics and law. Theory must follow society rather than the other way round.

Hence, in the author's opinion, crossing the boundaries between private and public law by the new EU law implementing the EGD policy does not deserve the criticism but relatively close attention. Only the implementation of these actions will show to what extent they are a one-off attempt and to what extent they set new, lasting trends and standards, sending the current standard divisions to the history of law.

\footnotetext{
${ }^{28}$ Bojar-Fijałkowski T, O Wypieraniu Norm i Instrumentów Administracyjnoprawnych Przez Normy $i$ Instrumenty Cywilnoprawne w Prawie Publicznym, ed. B. Bajor and P. Saganek (Warszawa: EWSPA, 2018).

${ }^{29}$ Szuber-Bednarz E. T and Paczuski R, Wypieranie Prawa Administracyjnego Przez Prawo Cywilne Czy Także Wspomaganie Osiagania Celów Administracyjno-Prawnych Droga Stosowania w Coraz Szerszym Zakresie Umowy Jako Cywilnoprawnej Formy Działania?, ed. A. Doliwa and S. Prutis (Warszawa: Wolters Kluwer, 2012).

${ }^{30}$ Langrod J. S, Zarys Prawa Administracyjnego: Zarys Części Ogólnej (Kraków: Wolters Kluwer, 2003).

${ }^{31}$ Safjan M, Pojęcie i Systematyka Prawa Prywatnego.
} 


\section{Conclusion}

The above study entitles to the following conclusions, assessments and de lege ferenda postulates:

- "European Green Deal", the hitherto political doctrine, is becoming common law. What is more, the EU legislator, where it is still possible, is pushing up standards and limits to reduce greenhouse gas emissions. These actions are further accelerated by the SARSCoV-2 pandemic and the desire to use EGD, beyond the climate sphere, to stimulate and rebuild the EU member states economies. The implementation of the EGD will affect many branches of law and many areas of activity, including main business activity. With this process, more than ever before, the idea of sustainable development will take on real shape and concrete legal norms in the European Union.

- Renewable energy and the development of the "Circular Economy" occupy an important place among the instruments for realising the above assumptions. Thus, from the level of declarations, as was typical for the era of sustainable development, the EU legislator moves to the real economy, directly indicating the role of the environment as an imperative for business law or even a public law in general. In this area, regulations have already been introduced, which is a novelty equipped with ius cogens norms, establishing rules for eco-design of household electronic equipment: limits for durability and personal savings, the possibility and ease of repair, delivery times for spare parts. Regulations are being prepared in the areas of public procurement, competition law, construction and transport. Standards are being developed to encourage broader and better consumer choice through leasing, renting, or sharing services while safeguarding consumer interests regarding costs, safety, information, contractual conditions, and insurance.

- At the same time, modern law is finding it increasingly difficult to fit into traditional divisions. Mixed private and public law institutions, hybrid entities, are emerging. We observe both the penetration of private law into the traditional public-law sphere and public law into the sphere of relations hitherto covered by freedom of contract and freedom of entrepreneurship. An example of such penetration, or interference, are the assumptions of the EGD and CE regulations affecting private-law relations, civil law and commercial law.

- The process of supplanting or replacing public law norms with private law norms is evident in real estate management law, public procurement, environmental law, municipal management, public management. It seems inevitable, as it is in line with, among other things, the constitutional principle of economic freedom and postulates of new trends in public administration aimed at increasing public participation in administration. At the same time, the visual interpretation of private and public law in the activity of public administration bodies does not have to mean displacement of public law, but only cooperation and mutual complementation.

- EU lawmaker is often crossing the boundaries between the sphere of individual rights and the sphere of the dominion of state authority. The issue of expanding the areas of standard EU regulations may also be brought. Doubts should also be raised as to the stability and homogeneity of the legal system as we know it. On the other hand, traditional divisions do not necessarily correspond with the challenges of today's dynamic society and economy. Theory must follow society rather than the other way round and allow hybrid solutions. Crossing the boundaries between private and public law does not deserve criticism, relatively close attention and observations. Only the new EU law implementing the EGD policy will show to what extent they are a one-off 
attempt and to what extent they set new, lasting trends and standards, sending the current standard divisions to the history of law.

\section{Bibliography}

\section{A. Journal}

Evans, Stuart, Michael A. Mehling, Robert A. Ritz, and Paul Sammon. "Border Carbon Adjustments and Industrial Competitiveness in a European Green Deal." Climate Policy 21, no. 3 (2021): 307-17. https://doi.org/10.1080/14693062.2020.1856637.

Gregson, Nicky, Mike Crang, Sara Fuller, and Helen Holmes. "Interrogating the Circular Economy: The Moral Economy of Resource Recovery in the EU." Economy and Society 44, no. 2 (2015): 218-43. https://doi.org/10.1080/03085147.2015.1013353.

Hobson, Kersty. "The Limits of the Loops: Critical Environmental Politics and the Circular Economy." Environmental Politics 30, no. 1-2 (2021): 161-79. https://doi.org/10.1080/09644016.2020.1816052.

Oberthür, Sebastian, and Claire Dupont. "The European Union's International Climate Leadership: Towards a Grand Climate Strategy?" Journal of European Public Policy 28, no. 7 (2021): 1095-1114. https://doi.org/10.1080/13501763.2021.1918218.

Powałowski, Andrzej. "Skarb Państwa a Działalność Gospodarcza [State Treasury and Economic Activity]." Gdańskie Studia Prawnicze, 2017, 527-38. https://prawo.ug.edu.pl/sites/default/files/_nodes/stronapia/33461/files/38powalowski.pdf.

Sadeleer, Nicolas De. "EU Environmental Law and the Internal Market." Review of European, Comparative \& International Environmental Law 26 (2014): 101-2. https://doi.org/10.1111/reel.12191.

T, Bojar-Fijałkowski. "On the Ideas Shaping European Union Environmental Law. Part I: From Sustainable Development." Problemi Mižnarodnih Vidnosin 13 (2018): 148-66. https://repozytorium.bg.ug.edu.pl/info/article/UOG797cd3383d334e2e9cf1df193f729022 $/$ ?ps=20\&lang=en\&pn=1\&cid=201\#.YYCw3J5BzIU.

\section{B. Books}

Bojar-Fijałkowski T. Gospodarka o Obiegu Zamkniętym Jako Model Rozwoju Unii Europejskiej - Wyzwania Dla Wybranych Sektorów. Edited by M. Królikowska-Olczak and C.H. Beck. Warszawa: problematyka prawna, 2018.

- O Wypieraniu Norm i Instrumentów Administracyjnoprawnych Przez Normy $i$ Instrumenty Cywilnoprawne w Prawie Publicznym. Edited by B. Bajor and P. Saganek. Warszawa: EWSPA, 2018.

Bugge, Hans Christian, and Christina Voigt. Sustainable Development in International and National Law: What Did the Brundtland Report Do to Legal Thinking and Legal Development, and Where Can We Go from Here? Portland: Avosetta, 2008.

Bukowski, Zbigniew. Gospodarka o Obiegu Zamkniętym a Prawo Ochrony Środowiska. Edited by Bojar-Fijałkowski T. Gdansk, 2016.

J, Ciechanowicz-McLean. Prawo i Polityka Ochrony Środowiska. Edited by Anna Hara. Warszawa: Wolters Kluwer, 2009.

Langrod J. S. Zarys Prawa Administracyjnego: Zarys Części Ogólnej. Kraków: Wolters Kluwer, 2003.

Safjan M. Pojęcie i Systematyka Prawa Prywatnego. Edited by M. Safjan. Warszawa: Wolters Kluwer, 2007.

T, Bojar-Fijalkowski, and Cern G. Ograniczenia Działalności Gospodarczej Spółki 
Komunalnej - Uwagi Krytyczne [Restrictions on the Economic Activities of a Municipal Company - Critical Remarks. Edited by A. Pławska M. Geryk. Gdansk: WSZ, 2016.

T, Szuber-Bednarz E., and Paczuski R. Wypieranie Prawa Administracyjnego Przez Prawo Cywilne Czy Także Wspomaganie Osiagania Celów Administracyjno-Prawnych Droga Stosowania w Coraz Szerszym Zakresie Umowy Jako Cywilnoprawnej Formy Działania? Edited by A. Doliwa and S. Prutis. Warszawa: Wolters Kluwer, 2012.

\section{Regulations}

Constitution of the Republic of Poland, Pub. L. No. 483 of 2 April 1997, 2413 (1997).

Council of the European Union. Regulation (EU) 2021/1119 establishing the framework for achieving climate neutrality ('European Climate Law'), Pub. L. No. 2021/1119, 1 (2021).

European Parliament and Council. Directive 2005/32/EC of the European Parliament and of the Council of 6 July 2005 establishes a framework for setting ecodesign requirements for energy-using products and amending Council Directive 92/42/EEC and Directives 96/57/EC and 2000/55/EC, Pub. L. No. 191, 22.7.2005, 29 (2005).

The Republic of Poland. Polish Code of Administrative Procedure (1960). http://www.parliament.am/library/varchakaniravaxaxtum19/lehastan.pdf.

The European Commission. COMMUNICATION FROM THE COMMISSION TO THE EUROPEAN PARLIAMENT, THE COUNCIL, THE EUROPEAN ECONOMIC AND SOCIAL COMMITTEE, and the REGIONS' COMMITTEE Towards a circular economy: A zero waste programme for Europe (2014).

. "“EU', a Political and Legal Community of 27 European States.” European Union, 2021. https://doi.org/10.2775/5377.

- EU green public procurement criteria for road lighting and traffic signals (2018).

- European Green Deal (2019). https://www.unido.org/sites/default/files/files/202011/EU_Green_Deal_2020.pdf.

laying down ecodesign requirements for refrigerating appliances under Directive 2009/125/EC of the European Parliament and the Council and repealing Commission Regulation (EC) No 643/2009, Pub. L. No. (EU)2019/2019, 2019187 (2019). 
